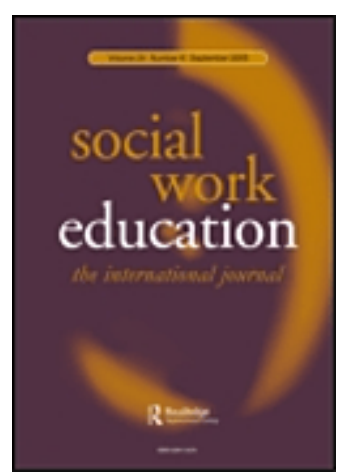

\title{
What do we know the experiences and outcomes of anti- racist social work education? An empirical case study evidencing contested engagement and transformative learning
}

\begin{tabular}{|r|l|}
\hline Journal: & Social Work Education \\
\hline Manuscript ID & CSWE-2018-0169.R1 \\
\hline Keywords - free form: & $\begin{array}{l}\text { Anti-racism, anti-racist social work, critical pedagogy, emancipatory } \\
\text { education, measuring educational outcomes, mixed methods, research, } \\
\text { race equality, researcher identity, positionality, transformative learning. }\end{array}$ \\
\hline Keywords: & $\begin{array}{l}\text { 'Race' and ethnicity < Values, Research minded practice < Research, } \\
\text { Quantitative methods < Research, Anti-discriminatory practice }< \\
\text { Education, Higher education < Education, Pedagogies < Education, } \\
\text { Diversity < Values, Critical incident analysis < Practice, Equalities < } \\
\text { Values, Multi-cultural perspectives < Values }\end{array}$ \\
\hline \multicolumn{2}{|l}{} \\
\hline
\end{tabular}

\section{SCHOLARONE Manuscripts}





\title{
What we know about the experiences and outcomes of anti-racist social work education? An empirical case study evidencing contested and transformative learning.
}

\begin{abstract}
In social work education there have been very few attempts to empirically capture and measure how professional training programmes prepare students to work with 'race' equality and cultural diversity issues (Williams \& Parrott, 2013). This paperinterrogates the experiences and outcomes of anti-racist social work education and evaluates the pedagogic relevance and practice utility of teaching social work students about 'race', racism and anti-racism (Singh,2014). The data presented in this paper suggests that it is possible to discover the situated experiences of learning about anti-racism and measure how this teaching can affect and lead to knowledge, skills and attitudinal change (Carpenter, 2005; 2011). The triangulated mixed methods evidence presented in this paper combines nomothetic and idiographic approaches with quantitative data for a matched pair sample of 36 social work students and uses non-parametric statistical tests to measure at two time intervals (before and after teaching); knowledge, skills and attitudinal change. The paper explores how anti-racist social work education enables students to move from 'magical consciousness' (Friere,1970), where racism and racial oppression is invisible and thereby left unchallenged and maintained, to more critical and reflexive level of awareness where it is named, challenged and no longer shrouded in a culture of professional denial and silencing.
\end{abstract}

\section{Key words}

Anti-racism, anti-racist social work, critical pedagogy, emancipatory education, measuring educational outcomes, mixed methods research, race equality, researcher identity, positionality, transformative learning. 


\section{Introduction}

Evidencing learning which is experienced as transformative and leading to 'perspective transformation' (Mezirow, 1981), and 'critical consciousness' through the process of conscientization (Freire, 1970) enables us to understand important moments in learning and how they lead to a more critical understanding of the social world. How social work students engage and make sense of teaching on anti- racism and the diverse footprints it leaves behind is captured in different strands of empirical evidence presented in this paper which is suggestive of both transformational change and contested engagement with learning.

This paper begins by mapping out the contemporary nature of British racism and interrogating social works engagement with anti-racist practice before moving onto consider the methodological design and empirical findings from a mixed methods research study. This research presented in this paper sought to understand and evidence how learning on anti-racism is experienced and the different types of educational outcomes it can lead to.

In the pursuing discussion I draw upon terms which have complex and contested meanings in academic, political or public spheres of discourse (Goldstein, 2008). These terms refer to how 'race', racism and ethnicity are conceptualised and the processes of representation, exploitation and domination (Downing and Husband, 2005). These terms are used throughout this paper to understand how the difference of 'others' is sometimes conceived, represented and encountered in professional social work training contexts (Sharma, 2006).

\section{The context of British social work practice- the saliency of 'race' and racism in a supposedly post racial society}

Britain's Black and minority ethnic communities now constitute $20 \%$ of the population of England and Wales (Joseph Rowntree Foundation, 2012) and have generally evolved 
from the diasporas associated with post-war immigration. However these communities are not homogenous and are comprised of a plurality of ethnic identities. They encompass a number of separate groups who differ in language, religion and history (Modood, 1992). Whilst some of these groups may assert a racial identity based on experiences of racism, others may focus on country of origin, religion and some may even privilege hyphenated identities (Modood, 2013).

The available research evidence suggests that, while the force and expression of racism may be changing, Britain's Black and minority ethnic communities continue to experience sustained and embedded racial inequalities (Race Disparity Audit, 2017). Evidence suggests that the socio-economic position and general life experiences of Black and minority ethnic communities is different from their white British counterparts (Platt, 2011); and that racial inequality has remained persistent and entrenched. The Equality and Human Rights Commission report 'Is Britain Fairer?' (EHRC,2018) identifies the cumulative nature of racial inequality and poverty across an individual's lifespan and the different 'ethnic penalties' these groups experience. Therefore despite the best efforts of UK 'race' legislation and 'race' equality policies, most minority groups, and women in the continue to experience disproportionate levels of marginalisation and disadvantage (Khan \& Shaheen, 2017). Such experiences will characterise the lives of Black and minority ethnic service users and compound existing social problems.

\section{The experiences of Black and minority ethnic service users}

It is generally difficult to comment upon the specific experiences of Black and minority ethic service users, given the dearth of research undertaken in this area. Singh (2011) suggests the failure of mainstream research to record the experience of Black and minority ethnic service users has effectively rendered them invisible. He questions the reluctance of researchers to explore why Black and minority ethnic service users tend to be congregated in the controlling aspects of service provision and under-represented in the welfare and supportive aspects of provision. 
The limited research activity which addresses 'race' issues in British social work practice contexts continues to paint a familiar picture by suggesting that for Black service users and workers "racism remains a major problem" (Singh, 2006 p.73), which is particularly acute in rural areas of Britain, where Black staff and service users will be socially isolated (Butler et al., 2003). Research has also found that that because of the "perceived cultural distance of South Asian clients there may be a tendency to be less able to empathise appropriately with them" (Banks, 1999, p.248); and that practitioner judgements may be based on 'heuristical notions' of Asian people and culture and lead to 'associated biases' (Patel \& Strachan,1997), sometimes leading to 'cultural stereotypes' and 'unconscious bias' about particular groups and the assumption that 'informal or family support is always available', resulting in some communities having to 'look after their own' (Butt, 2006, p.7).

Butt (2006) also draws upon empirical work which helps us to understand how white workers experience working with Black and minority ethnic staff and service users:

- white workers claiming that they do not possess the skills and experience to work with Black and minority ethnic families,

- white managers being unable to provide direction to Black and minority ethnic workers,

- white workers experiencing fear of being described and labelled as racist and therefore being unsure about intervening (Butt, 2006, p.7). Also see Casey Report (2015) about how the professional fear of being branded racist had safeguarding implications for dealing with Asian perpetrators of child sexual exploitation in Rotherham, UK.

Research which focuses on levels of service engagement suggests that because of problems with cross cultural communication and lack of ethnically sensitive service provision, which is often exacerbated by a lack of cultural awareness, Black and minority service users are hesitant and lack confidence in accessing services (Laird, 2008; Gilligan \& Furness, 2010). This is particularly the case for mental health services, where research has reported 'circles of fear' which stop Black people from seeking professional help. These 'circles of fear' are related to Black services users experiencing a lack of respect 
Therefore Barn suggests that "Black families would like not only better access to existing services, but also services that recognise ethnic, cultural and religious diversity" (Barn, 2006, p.3). The accumulative research seems to suggest that in terms of working with Black and minority ethnic service users and families the complex interaction between the 'hand, head and the heart', reframed in the work of Dominelli, "as the integration of practice skills, intellectual understanding and emotional capacities [including empathy] of the individual practitioner in interaction with those of the client" (Dominelli, 2002, p.64), is seen to be wanting and compromises the appropriateness and quality of professional social work responses. 


\section{The contours of British Anti-racist social work}

In many respects a focus on 'identity' is a central preoccupation of anti-racist social work practice, which has been referred to as a set of disparate polycentric overlapping practices and discourses (Anthias \& Lloyd, 2002). The focus for anti-racist social work remains on the institutional and structural nature of racism and how it is reproduced in state institutions, including social work education and practice contexts (McLaughlin, 2005). In contrast to the liberal character of the terms used by multiculturalists, such as equality, culture, competence, prejudice, customs, ignorance, fairness, and opportunity, anti-racist practitioners and academics have tended to draw upon more hard-edged politicised terms concerned with struggle, structure, power, exploitation and resistance. (Gillborn \& Ladson-Billings, 2004). These terms demonstrate why anti-racist social work is considered to be a politically committed form of practice (Tomlinson, 2002), a radical and oppositional project which emphasises the need to actively identify and resist racism (Bonnet \& Carrington, 1996).

The usefulness of anti-racist perspectives which have a valuable and transformative role in social work education can be identified in a number of areas that include:

- empowering students to identify and name racism (Goldstein, 2008),

- raising awareness of racial inequalities and the processes associated with racial oppression, racial marginalisation and racial exclusion (Bhatti-Sinclair,2011; Lavalette \& Penketh,2014),

- transforming unequal social relations, shaping intercultural encounters into equal ones by raising self-awareness of prejudices, biases and stereotypes in individual interpersonal relationships (Dominelli, 1988).

- exploring the social construction, normativity and 'race' privilege associated with white culture and 'Whiteness' and deconstructing the hegemony of the 'white mythical norm' (Jeyasingham, 2012).

Other writers have focused on how anti-racist perspectives challenge representations of Black people in popular culture (Downing \& Husband, 2005) and their social construction as 'dangerous' which may lead to inappropriate and oppressive social work interventions (Keating, 2012; Fernando,2014). Kohli also suggests that anti-racist 
perspectives play a valuable role in drawing attention to asylum seekers who find themselves vilified, detained, dispersed and deported (Kohli, 2007).

Singh suggests that the overall effect of this learning enables social work students to realise that

The wider struggles against state sponsored racism, against the asylum, immigration and nationality laws, against deaths in police custody, against stop and search, against racism in the judicial system, against school exclusions, against the premature deaths of black people due to health inequalities, and against the economic policies leading to the devastation of inner cities where the vast majority of black people live are always relevant to worker-client interactions (Singh, 2002, p. 77).

However the irony for British social work education is that the limited research which has been published on this area of teaching suggests there are 'fundamental questions' about the way students learn about these issues and that anti-racism remains largely 'invisible and insignificant' in student work (Heron, 2004, p.289; Heron, 2008). Penketh, (2000) in her seminal work also found that white students often work 'unknowingly' or 'unquestioningly' in practice learning settings with little concern for issues of antiracism.

The research reported below offers new insights into how this learning is experienced by contemporary social work students and how it can be measured to demonstrate professional preparedness for practising in a multicultural society.

\section{Methodology}

The study adopted a mixed methods research approach which offered opportunities for data triangulation (Bulmer, 2004) and working simultaneously across different sets of findings, which provided the research with greater levels of credibility and dependability (Orme \& Shemmings, 2010). The combined use of both quantitative and qualitative 
research approaches within the same study was suggestive of a pragmatic approach which advocated a position of methodological pluralism (Bryman, 2006). It was also suggestive of a logic of enquiry which included the use of induction (to discover patterns and build grounded theory) and deduction which involved testing theories and hypothesis (Johnson \& Onwuegbuzie, 2006).

The research was undertaken using a case study approach at one University in England and the findings may be illustrative of experiences across the sector. Ethical permission was granted for this mixed methods study and students were recruited to participate in this research from a taught stand-alone module which addresses anti-racism in social work practice.

The desired aims of this study were not solely to measure change but to also discover how anti-racist social work education was experienced, the challenges and barriers associated with engaging with this area of learning and identifying what worked best for students with different learning needs and experiences (Pawson \& Tilley, 1997).

\section{Research study design and methods}

The empirical fieldwork encompassed two different strands of data collection. The first was in relation to the collection of matched pairs questionnaire data at two time intervals, before (T1) and after (T2) modular teaching. This questionnaire included likert scales, confidence interval scales and opportunities for qualitative written feedback on different aspects of learning and teaching. These qualitative strands of data were designed to capture skills and knowledge development, critical and transformative moments in learning and how different positionalities and experiences shaped engagement with educational content. The second strand of data collection included student group interviews at the end of module teaching and a content analysis of modular/programme learning documentation.

Research instruments were piloted to ensure that they captured quantifiable aspects of data and individual and shared social constructions of experience. The research drew upon a purposive sampling strategy and although matched pair sample numbers were 
low (36 students) it was still possible to "compare and contrast individuals located in different subjectivities" (Gray, 2003, p. 100). However the limitations of the low sample size needs to be carefully considered when interpreting the findings of nonparametric statistical tests undertaken to compare group differences related to 'race', age and experience of working with a Black and minority ethnic service user. For example, when comparing a sample size of 12 Black students with 24 white students, the difference would need to be high to achieve statistical significance.

Despite these methodological limitations the findings reported in this paper are suggestive of a range of experiences and different learning outcomes which have left a complex set of footprints in relation to how anti-racist social work education is experienced and evidenced.

\section{Measuring educational outcomes}

In order to measure educational outcomes the study drew upon the seminal work of Carpenter $(2005 ; 2011)$, who suggests it that is possible to evaluate the outcomes of social work education and assess the impact of professional education on practice. Carpenter (2005) [after Kirkpatrick (1967) and Barr et al., (2000)] identifies four different levels of outcomes of educational programmes:

\section{Level 1: Learners' Reaction}

Level 2a: Modification in Attitudes and Perceptions

Level 2b: Acquisition of Knowledge and Perceptions

Level 3a: $\underline{\text { Changes in Behaviour }}$

Level 3b: Changes in Organisational Practice

Level 4: Benefits to Users and Carers (Carpenter, 2005; 2011).

These four different levels encompass the domains of knowledge, skills, attitudes and behaviour and enable us to measure specific learning outcomes and evaluate whether students learn and apply what we as social work educators hope for. This model 
promotes accountable educational practice by examining if what we are teaching is effective and whether it enables students to "learn the knowledge, skills and attitudes intended, in line with specified learning outcome" (Burgess \& Carpenter, 2010, p.8). Figure 1 below describes how Carpenter's level one and level two educational outcomes were drawn upon to measure and capture the outcomes of teaching on anti-racism.

Figure 1, Measuring the outcomes of anti-racist social work education

\section{Level 1 \\ Learners' Reaction}

Measured at T2 in questionnaire data addesssing impressions of learning experience, levels of engagement with teaching content and whether this addressed specific learning needs. Also explored in student group interviews
Level $\mathbf{2 b}$

Acquisition

Level $2 a$

Modification

in Attitudes

\& Perceptions

Measured in matched pairs questionnaire data and likert scales focusing on awareness, confidence and perceptions of racial equality. Also explored in student group interviews of Knowledge \& Skills

Measured in matched pairs questionnaire data and likert scales focusing on knowledge of 'race' issues and key skills for multicultural practice. Also explored in student group interviews 


\section{Findings}

\section{Student learning needs}

Students were asked to reflect upon what their learning needs were in relation to this area of teaching and whether these had been met. Students identified a range of learning needs. The majority of students identified race awareness training and a practical understanding of anti-racist perspectives in social work practice as key learning needs. However a sizeable group of students $(\mathrm{N}=8)$ identified cultural awareness as a key learning need, and this was interesting finding given the absence of cultural awareness training as a discrete aspect of learning. When this data was cross tabulated with 'race' and age it emerged that students identifying cultural awareness training as a key learning requirement were all white and clustered in the under 26 age range (see table 1 and 2).

Table 1 Student learning needs - 'race' cross tabulation

\begin{tabular}{|c|l|l|l|l|l|}
\hline & \multicolumn{5}{|l|}{ Student learning needs - 'Race' Cross tabulation } \\
\cline { 2 - 7 } & $\begin{array}{l}\text { Non } \\
\text { stated }\end{array}$ & $\begin{array}{l}\text { Anti-racist } \\
\text { social work } \\
\text { practice }\end{array}$ & $\begin{array}{l}\text { Awareness } \\
\text { of racism }\end{array}$ & $\begin{array}{l}\text { Impact of } \\
\text { racism on } \\
\text { Black staff }\end{array}$ & $\begin{array}{l}\text { Cultural } \\
\text { awareness/ } \\
\text { competence }\end{array}$ \\
\hline \multirow{2}{*}{ White students } & 2 & 3 & 16 & 0 & 8 \\
\hline Total & 0 & 6 & 10 & 3 & 0 \\
\hline
\end{tabular}

Table 2 Student learning needs - age cross tabulation

\begin{tabular}{|ll|l|l|l|l|l|}
\hline \multirow{2}{*}{} & \multicolumn{5}{|l|}{ Student learning needs - Age Cross tabulation } \\
\cline { 2 - 7 } & $\begin{array}{l}\text { Non } \\
\text { stated }\end{array}$ & $\begin{array}{l}\text { Anti-racist } \\
\text { social work } \\
\text { practice }\end{array}$ & $\begin{array}{l}\text { Awareness of } \\
\text { racism }\end{array}$ & $\begin{array}{l}\text { Impact of } \\
\text { racism on } \\
\text { Black Staff }\end{array}$ & $\begin{array}{l}\text { Cultural } \\
\text { awareness }\end{array}$ \\
\hline \multirow{2}{*}{ Age } & Under 26 & 0 & 4 & 13 & 0 & 5 \\
\cline { 2 - 7 } & Over 26 & 2 & 5 & 13 & 3 & 3 \\
\hline
\end{tabular}


It was also noticeable that only Black students identified addressing the impact of institutional and personal racism on Black workers as a learning need. This was an interesting finding and suggested that for these students developing skills and strategies for working in predominately white organisations was a particular aspect of lived experience which they wanted learning to address. However a documentary analysis of the module specification, suggested that addressing the experiences of Black social workers in white organisational spaces and enabling Black students to develop strategies to counteract institutional and overt forms of racism, was not an area of teaching identified in indicative module content and learning outcomes. The absence of curricula content in this area may have had consequences for how Black students managed micro aggressions in practice education and classroom settings and how they made developed strategies to challenge and make sense of other expressions of racialised power (Spencer, 2018).

\section{Measuring Educational Outcomes (issues and skills for effective anti- racist practice)}

At two different time intervals, before and at the end of module teaching, students were asked to identify in questionnaires key issues and skills which they considered to be important for anti-racist social work practice. These handwritten matched pair responses were coded and analysed to identify skills development and change over the course of module learning. The data suggested that at the end of the educational intervention students were able to evidence a wider repertoire of issues and skills for anti-racist practice which were demonstrative of new learning and professional development. The number of issues and skills they could identify (see tables 3-6) increased and this change was attributable to the classroom based teaching and blended learning materials. Students at $\mathrm{T} 2$ were able to name racism and consider a wider range of multicultural skills and issues for effective practice. 
Table 3 Key Issues identified by Age at T1

\begin{tabular}{|c|c|c|c|c|}
\hline & \multicolumn{2}{|l|}{ Age } & \multirow[t]{2}{*}{ Total } \\
\hline & & Under 26 & Over 26 & \\
\hline \multirow{9}{*}{$\begin{array}{l}\text { Before teaching } \\
\mathrm{T} 1 \\
\text { Issues }\end{array}$} & $\begin{array}{l}\text { Lack of knowledge and } \\
\text { understanding about } \\
\text { different cultures }\end{array}$ & $7(41 \%)$ & $8 \quad(42 \%)$ & 15 \\
\hline & $\begin{array}{l}\text { Cross Cultural } \\
\text { Communication Problems }\end{array}$ & 0 & $6 \quad(32 \%)$ & 6 \\
\hline & Racism & $6(35 \%)$ & $12(63 \%)$ & 18 \\
\hline & $\begin{array}{l}\text { Immigration and Asylum } \\
\text { issues }\end{array}$ & $2(12 \%)$ & $2 \quad(11 \%)$ & 4 \\
\hline & $\begin{array}{l}\text { Transcultural Practice } \\
\text { Issues in Childcare, } \\
\text { Mental Health and work } \\
\text { with Older Adults } \\
\end{array}$ & $4(24 \%)$ & $3(16 \%)$ & 7 \\
\hline & $\begin{array}{l}\text { Access to Culturally } \\
\text { Appropriate Services }\end{array}$ & $5(29 \%)$ & $3(16 \%)$ & 8 \\
\hline & $\begin{array}{l}\text { Poverty and Social } \\
\text { Exclusion }\end{array}$ & $3(18 \%)$ & $2(11 \%)$ & 5 \\
\hline & $\begin{array}{l}\text { Specialist Black } \\
\text { Resources }\end{array}$ & $1(6 \%)$ & 0 & 1 \\
\hline & Total Issues identified & 28 & 36 & 64 \\
\hline
\end{tabular}


Table 4 Key Issues identified by Age at T2

\begin{tabular}{|c|c|c|c|c|}
\hline & \multicolumn{2}{|l|}{ Age } & \multirow[t]{2}{*}{ Total } \\
\hline & & Under 26 & Over 26 & \\
\hline \multirow{9}{*}{$\begin{array}{l}\text { After Teaching } \\
\text { T2 } \\
\text { Issues }\end{array}$} & $\begin{array}{l}\text { Lack of knowledge and } \\
\text { understanding about } \\
\text { different cultures }\end{array}$ & $4 \quad(24 \%)$ & $11(58 \%)$ & 15 \\
\hline & $\begin{array}{l}\text { Cross Cultural } \\
\text { Communication Problems }\end{array}$ & $1 \quad(6 \%)$ & $4 \quad(21 \%)$ & 5 \\
\hline & $\underline{\text { Racism }}$ & $15(88 \%)$ & $16 \quad(84 \%)$ & 31 \\
\hline & $\begin{array}{l}\text { Immigration and Asylum } \\
\text { issues }\end{array}$ & $6 \quad(35 \%)$ & $2 \quad(11 \%)$ & 8 \\
\hline & $\begin{array}{l}\text { Transcultural Practice } \\
\text { Issues in Childcare, } \\
\text { Mental Health and work } \\
\text { with Older Adults }\end{array}$ & $8 \quad(47 \%)$ & $5 \quad(26 \%)$ & 13 \\
\hline & $\begin{array}{l}\text { Access to Culturally } \\
\text { Appropriate Services }\end{array}$ & $2 \quad(12 \%)$ & $3 \quad(16 \%)$ & 5 \\
\hline & $\begin{array}{l}\text { Poverty and Social } \\
\text { Exclusion }\end{array}$ & $7 \quad(41 \%)$ & $4 \quad(33 \%)$ & 11 \\
\hline & $\begin{array}{l}\text { Specialist Black } \\
\text { Resources }\end{array}$ & $2 \quad(12 \%)$ & $1 \quad(5 \%)$ & 3 \\
\hline & Total Issues identified & 45 & 46 & 91 \\
\hline
\end{tabular}

Table 5 Key skills identified by Age at T1

\begin{tabular}{|c|c|c|c|c|c|c|}
\hline & & $A g$ & & & & Total \\
\hline & & & 26 & Ove & & \\
\hline & Communication & 14 & $(82 \%)$ & 15 & $(79 \%)$ & 29 \\
\hline & Cultural knowledge & 8 & $(47 \%)$ & 11 & $(58 \%)$ & 19 \\
\hline Before teaching & Empathy & 10 & $(59 \%)$ & 4 & $(21 \%)$ & 14 \\
\hline $\begin{array}{l}\text { T1 } \\
\text { Skills }\end{array}$ & $\begin{array}{l}\text { Reflexivity and self- } \\
\text { awareness }\end{array}$ & & $(24 \%)$ & & $(16 \%)$ & 7 \\
\hline & Ability to use interpreters & 0 & & 2 & $(11 \%)$ & 2 \\
\hline & Advocacy & 0 & & 1 & $(5 \%)$ & 1 \\
\hline & Total Skills identified & 36 & & 36 & & 72 \\
\hline
\end{tabular}


Table 6 Key skills identified by Age at T2

\begin{tabular}{|c|c|c|c|c|c|}
\hline & & \multicolumn{3}{|c|}{ Age } & \multirow{3}{*}{\begin{tabular}{|l|} 
Total \\
30 \\
\end{tabular}} \\
\hline & & \multicolumn{2}{|c|}{ Under 26} & Over 26 & \\
\hline \multirow{10}{*}{$\begin{array}{l}\text { After Teaching } \\
\text { T2 } \\
\text { Skills }\end{array}$} & Communication & 14 & $(82 \%)$ & $16 \quad(84 \%)$ & \\
\hline & Cultural knowledge & 12 & $(71 \%)$ & $13 \quad(68 \%)$ & 25 \\
\hline & Empathy & 4 & $(24 \%)$ & $7 \quad(37 \%)$ & 11 \\
\hline & $\begin{array}{l}\text { Reflexivity and self- } \\
\text { awareness }\end{array}$ & & $(35 \%)$ & $10 \quad(53 \%)$ & 16 \\
\hline & Ability to use interpreters & 1 & $(6 \%)$ & $3 \quad(16 \%)$ & 4 \\
\hline & Advocacy & 5 & $(29 \%)$ & $6 \quad(32 \%)$ & 11 \\
\hline & Authenticity and respect & 6 & $(35 \%)$ & $7 \quad(37 \%)$ & 13 \\
\hline & $\begin{array}{l}\text { Collaborative Strengths } \\
\text { based practice }\end{array}$ & & $(35 \%)$ & $2 \quad(11 \%)$ & 8 \\
\hline & Critical consciousness & & $(18 \%)$ & 0 & 3 \\
\hline & Total Skills identified & 57 & & 64 & 121 \\
\hline
\end{tabular}

\section{Graph 1 Skills and Issues identified by students at T1 and T2}

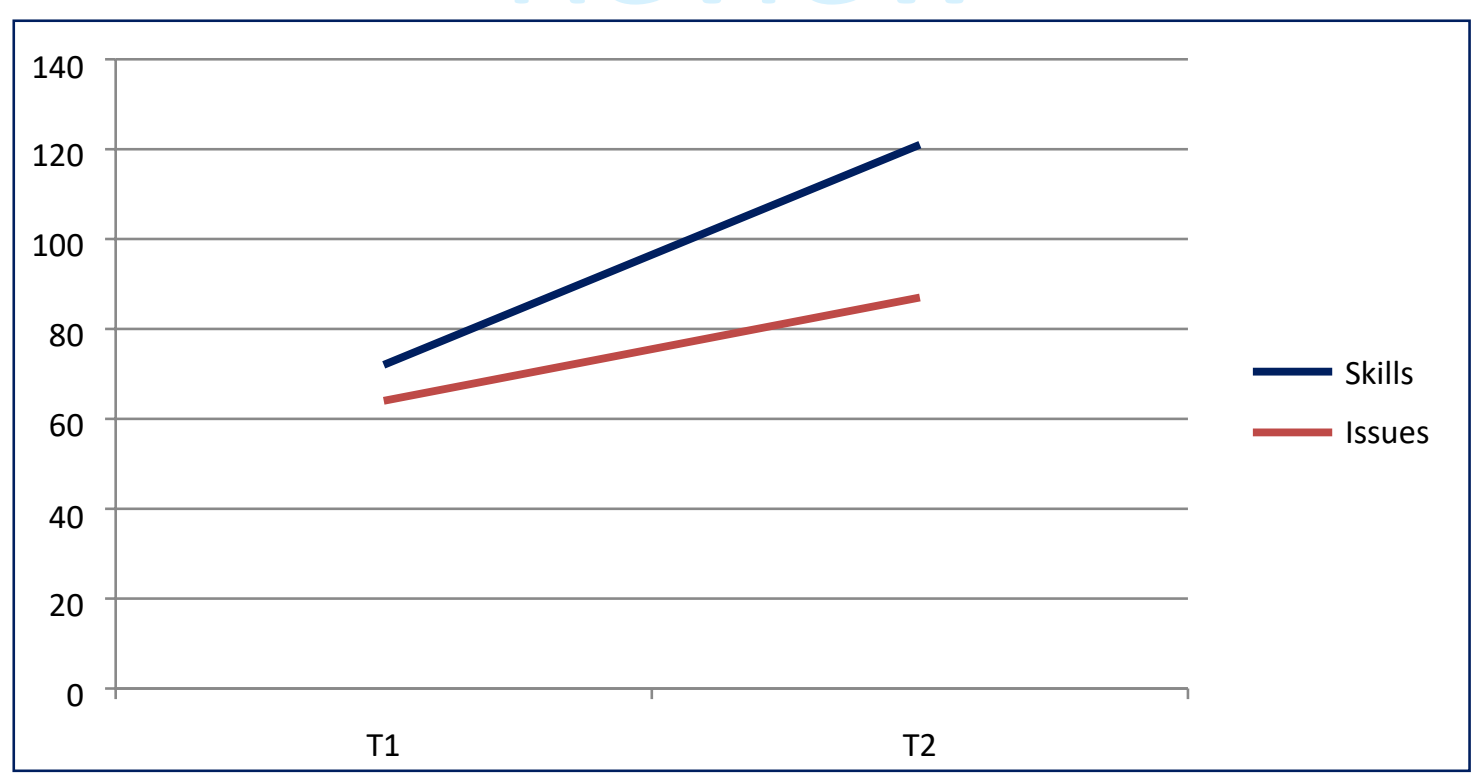

To test whether or not this change was statistically significant (see graph 1) a Wilcoxon Matched Pairs Signed Rank Test was carried out (see Table 7). The matched pair signed ranks test suggested that the increase in the number of skills and issues identified by students was statistically significant. 


\section{Table 7 Matched Pairs Signed rank test for skills and issues} Test Statistics ${ }^{a}$

\begin{tabular}{|c|c|c|}
\hline & \begin{tabular}{|l} 
T2 Number of \\
issues \\
identified - T1 \\
Number of \\
issues \\
identified \\
\end{tabular} & $\begin{array}{l}\text { T2 Number of } \\
\text { skills identified- } \\
\text { T1 Number of } \\
\text { skills identified }\end{array}$ \\
\hline $\begin{array}{l}\text { Z } \\
\text { Asymp. Sig. (2-tailed) }\end{array}$ & $\begin{array}{l}-2.581^{b} \\
.010\end{array}$ & $\begin{array}{l}-4.537^{b} \\
.000\end{array}$ \\
\hline
\end{tabular}

a. Wilcoxon Signed Ranks Test

b. Based on negative ranks.

\section{Measuring Educational Outcomes (practice confidence in working with cultural diversity)}

The empirical evidence also suggested a marked difference in the confidence levels of students to engage with anti-racism and work confidently with Black and minority ethnic service users. The findings suggested a significant overall change in practice confidence to work with different cultural groups and when this data was tested using the Wilcoxon matched pairs test the findings suggested that this increase in confidence from T1 to T2 was statistically significant (see Table 8).

\section{Table 8 Wilcoxon matched pairs test for overall confidence}

\begin{tabular}{|l|l|}
\hline & T2 Confidence \\
& - T1 Confidence \\
\hline$Z$ & $-2.985^{\mathrm{b}}$ \\
Asymp. Sig. (2-tailed) & .003 \\
\hline
\end{tabular}
a. Wilcoxon Signed Ranks Test
b. Based on negative ranks. 


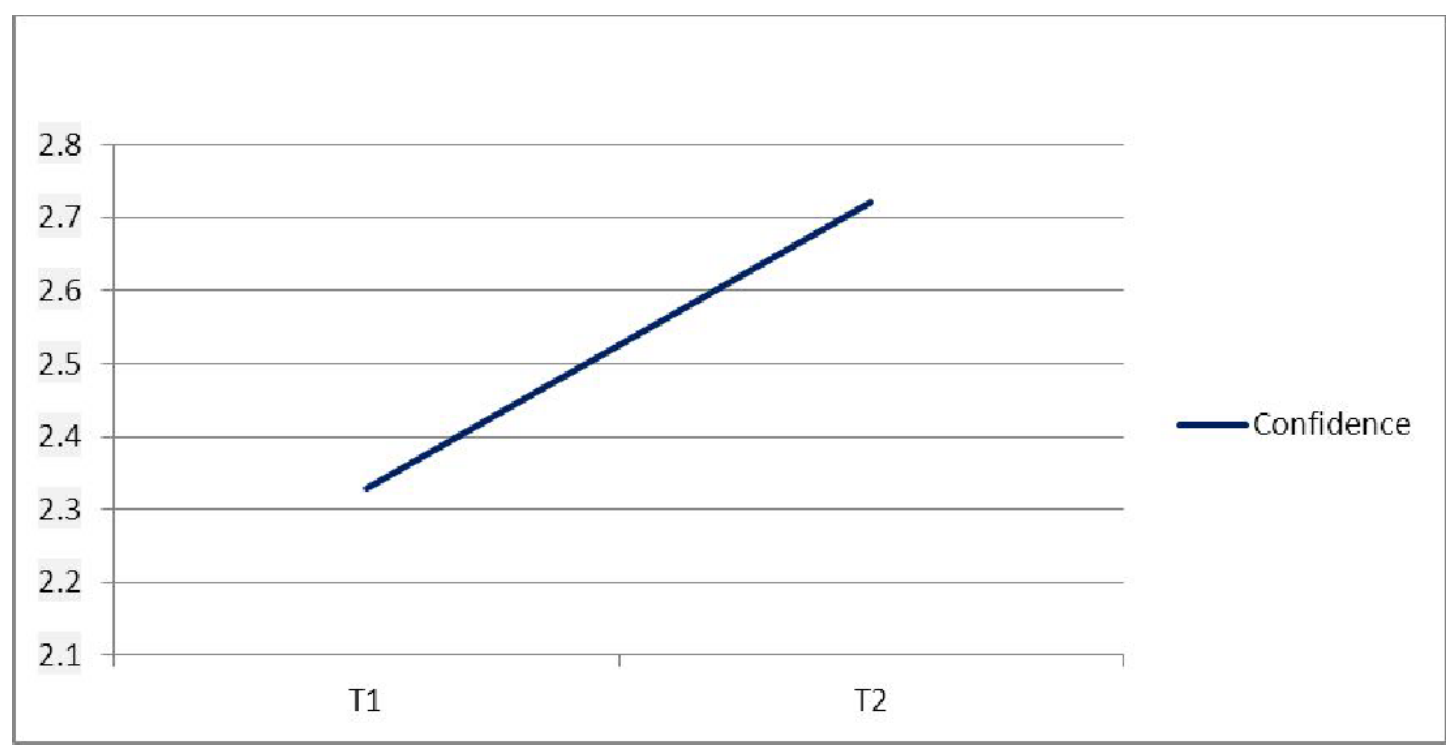

The mean score data for T1 and T2 suggested that Black students had higher levels of reported confidence for working with Black and minority ethnic service users compared with white students, but this was only statistically significant at T1. Another interesting strand of data also emerged in relation to students who had experienced working with a Black and minority ethnic service user in their first placement. These students compared to those who had not worked with a Black and minority ethnic service user at T1 had different levels of reported confidence. These students reported less confidence, compared with students who had not worked with a Black and minority ethnic service user. However at T2 these differences were no longer significant.

\section{Measuring Educational Outcomes (knowledge and awareness of anti-racism)}

The research data analysis also suggested a change in the mean scores for awareness of 'race' issues in social work (see Graph 3) and in how knowledgeable students felt about such issues (see Graph 4).

Graph 3 Awareness of 'race' issues in social work practice 


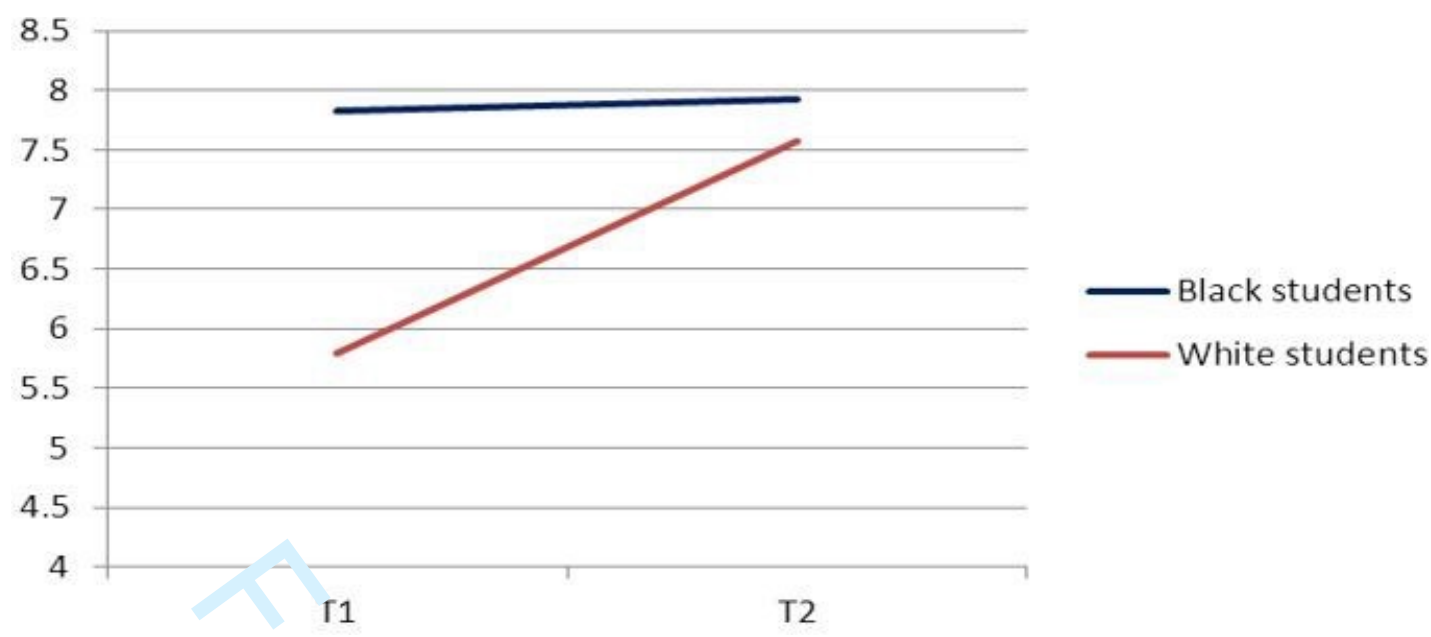

Graph 4 Knowledge of 'race' issues in social work practice

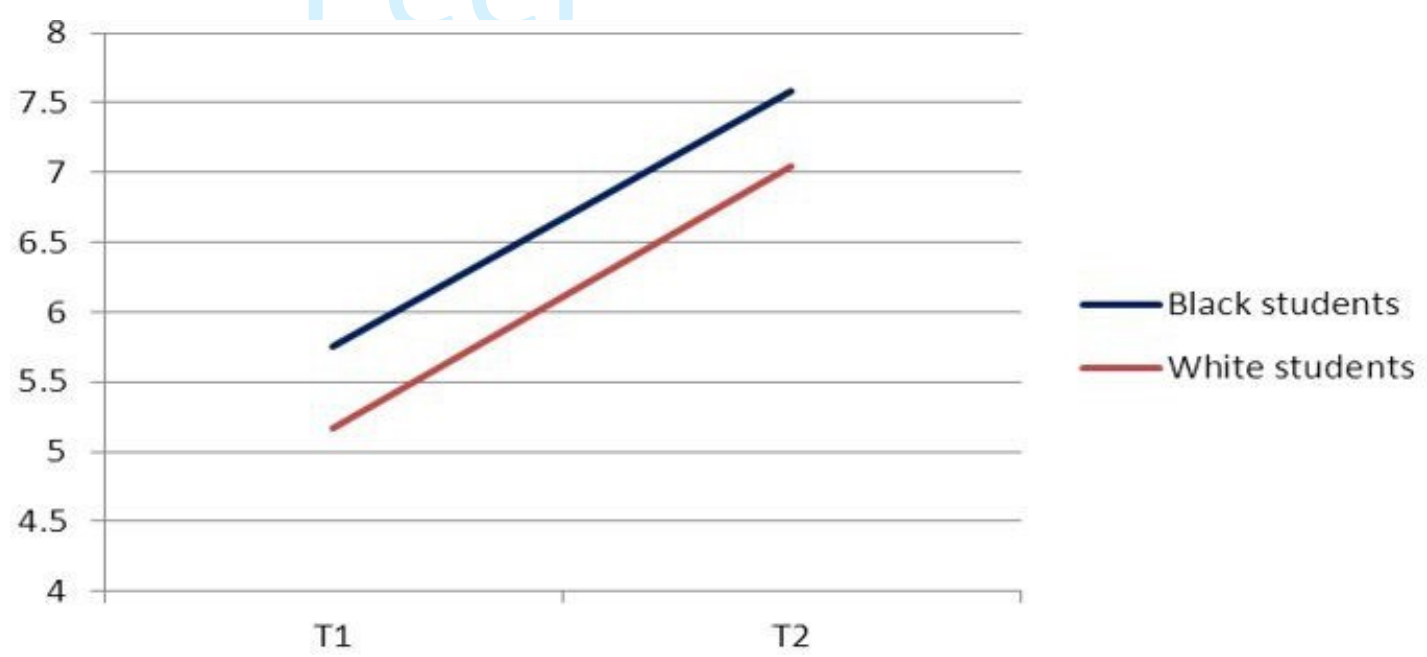

When data for awareness and knowledge was tested using the Wilcoxon matched pairs test the results suggested that the increase in both awareness and knowledge from T1 to $\mathrm{T} 2$ was statistically significant (see Table 9)

Table 9 Wilcoxon matched pairs test for awareness and knowledge 


\begin{tabular}{|c|c|c|}
\hline & $\begin{array}{l}\text { T2 Awareness } \\
\text { of 'race' issues - } \\
\text { T1 Awareness of } \\
\text { 'race' issues }\end{array}$ & $\begin{array}{l}\text { T2 Knowledge of } \\
\text { 'race' issues - T1 } \\
\text { Knowledge of } \\
\text { 'race' issues }\end{array}$ \\
\hline 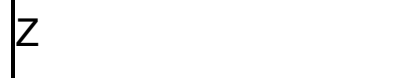 & $-3.266^{b}$ & $-4.554^{b}$ \\
\hline Asymp. Sig. (2-tailed) & .001 & .000 \\
\hline
\end{tabular}

However the mean score data suggested an important difference in the awareness levels between Black and white students (see Graph 3). Black students awareness of race and racism remained constant whilst for white students it evidenced positive change. When these differences were tested using the Mann Whitney U Test (see Table 10) they were found to be statistically significant at T1. This data suggests that teaching had more impact and was more critical for raising the 'race' awareness levels of white students as opposed to Black students.

Table 10 Mann-Whitney U Test for differences in Awareness and Knowledge associated with the 'race' (racial identity of the student)

\begin{tabular}{|l|l|l|l|l|}
\hline & $\begin{array}{l}\text { T1 Awareness } \\
\text { of 'race' issues }\end{array}$ & $\begin{array}{l}\text { T1 Knowledge } \\
\text { of 'race' issues }\end{array}$ & $\begin{array}{l}\text { T2 Awareness } \\
\text { of 'race' issues }\end{array}$ & $\begin{array}{l}\text { T2 Kno ledge } \\
\text { of 'race' issues }\end{array}$ \\
\hline Mann-Whitney U & 65.000 & 114.500 & 119.000 & 119.000 \\
Wilcoxon W & 365.000 & 414.500 & 419.000 & 419.000 \\
Z & -2.691 & -1.010 & -.894 & -.861 \\
Asymp. Sig. (2-tailed) & .007 & .313 & .372 & .389 \\
Exact Sig. [2*(1-tailed & $.007^{\mathrm{b}}$ & $.327^{\mathrm{b}}$ & $.416^{\mathrm{b}}$ & $.416^{\mathrm{b}}$ \\
Sig.)] & & & & \\
\hline
\end{tabular}

a. Grouping Variable: Ethnicity

b. Not corrected for ties. 
The empirical findings also suggested that young students developed greater awareness and evidenced more skills outcomes from teaching on anti-racism compared to their older counterparts. For young students teaching on anti-racism had greater educational outcomes and more impact on raising their knowledge, skills and awareness thresholds of what constitutes anti-racist practice and its utility for practice.

Graph 5 Scatterplot suggestive of a strong correlation between knowledge and awareness of anti-racism for students under the age of 26 at T2

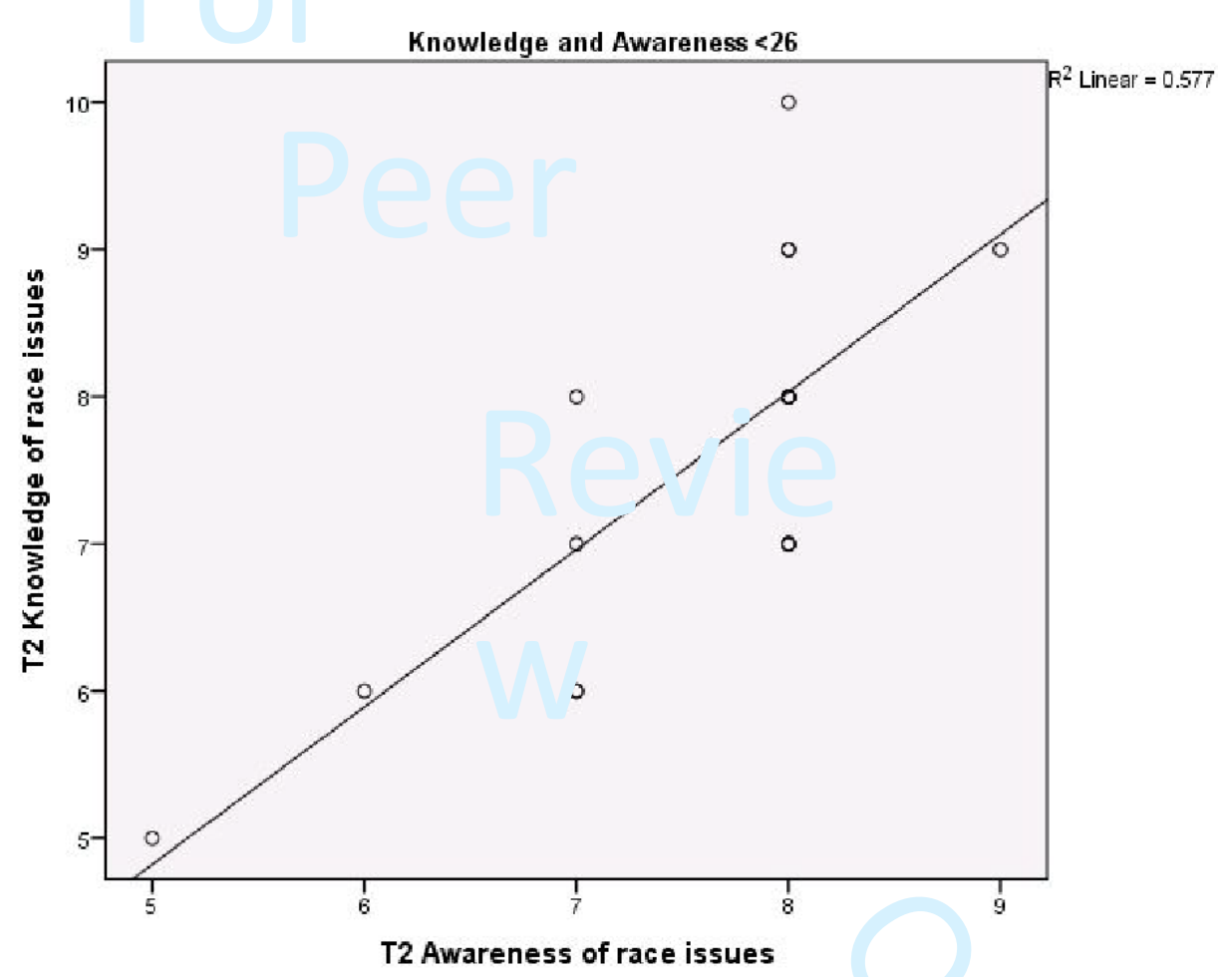

When this data for age was tested using the Spearman 's rank order (rho) non parametric test for a possible correlation, the high coefficient scores at T2 suggested that for students under the age of 26 there was indeed a strong relationship between their confidence, awareness and knowledge scores compared with students over the age of 26 (see Table 11). 
Table 11 Spearman's (rho) Correlation Coefficient Scores for Age-awareness, knowledge and confidence at $T 2$

\begin{tabular}{|c|c|c|c|c|c|c|}
\hline \multicolumn{4}{|l|}{ Age } & \multirow{2}{*}{$\begin{array}{l}T 2 \\
\text { Confidence } \\
1.000\end{array}$} & \multirow{2}{*}{\begin{tabular}{|l} 
T2 \\
Awarenes \\
s
\end{tabular}} & \multirow{2}{*}{$\begin{array}{l}\text { T2 } \\
\text { Knowledge } \\
.549^{*} \\
.022 \\
17 \\
\end{array}$} \\
\hline \multirow{3}{*}{$\begin{array}{l}\text { Under } \\
26\end{array}$} & \multirow{3}{*}{$\begin{array}{l}\text { Spearman's } \\
\text { rho }\end{array}$} & T2 Confidence & $\begin{array}{l}\text { Correlation } \\
\text { Coefficient } \\
\text { Sig. (2-tailed) } \\
N \\
\end{array}$ & & & \\
\hline & & T2Awareness & $\begin{array}{l}\text { Correlation } \\
\text { Coefficient } \\
\text { Sig. (2-tailed) } \\
N\end{array}$ & $\begin{array}{l}.525^{\star} \\
.030 \\
17 \\
\end{array}$ & $\begin{array}{l}1.000 \\
17\end{array}$ & $\begin{array}{l}.741^{* *} \\
.001 \\
17 \\
\end{array}$ \\
\hline & & T2Knowledge & $\begin{array}{l}\text { Correlation } \\
\text { Coefficient } \\
\text { Sig. (2-tailed) } \\
N\end{array}$ & $\begin{array}{l}.549^{\star} \\
.022 \\
17 \\
\end{array}$ & $\begin{array}{l}.741^{* *} \\
.001 \\
17 \\
\end{array}$ & $\begin{array}{l}1.000 \\
17\end{array}$ \\
\hline \multirow{3}{*}{$\begin{array}{l}\text { Over } \\
26\end{array}$} & \multirow{3}{*}{$\begin{array}{l}\text { Spearman's } \\
\text { rho }\end{array}$} & T2Confidence & $\begin{array}{l}\text { Correlation } \\
\text { Coefficient } \\
\text { Sig. (2-tailed) } \\
N\end{array}$ & $\begin{array}{l}1.000 \\
19 \\
\end{array}$ & $\begin{array}{l}273 \\
259 \\
19 \\
\end{array}$ & $\begin{array}{l}.661^{* *} \\
.002 \\
19\end{array}$ \\
\hline & & & $\begin{array}{l}\text { Correlation } \\
\text { Coefficient } \\
\text { Sig. (2-tailed) } \\
N\end{array}$ & $\begin{array}{l}273 \\
259 \\
19\end{array}$ & $\begin{array}{l}1.000 \\
19\end{array}$ & $\begin{array}{l}450 \\
.053 \\
19\end{array}$ \\
\hline & & T2Knowledge & $\begin{array}{l}\text { Correlation } \\
\text { Coefficient } \\
\text { Sig. (2-tailed) } \\
N\end{array}$ & $\begin{array}{l}.661^{* *} \\
.002 \\
19\end{array}$ & $\begin{array}{l}.450 \\
.053 \\
19\end{array}$ & 19 \\
\hline
\end{tabular}

*. Correlation is significant at the 0.05 level (2-tailed).

**. Correlation is significant at the 0.01 level (2-tailed).

This quantitative data was important for identifying and establishing how young and Black students engage differently with learning and how they evidence different types of outcomes which are associated with their age and racial identities. However the qualitative aspects of research were also able to identify other influences on learning which were significant for perspective transformation and positive educational outcomes. 


\section{Transformative moments in learning - critical incident analysis}

At T2 students were asked to identify a critical incident which had shaped and influenced their learning. Most students were able to identify a critical incident (see chart 1) but $19 \%$ of the group were unable to identify such an incident. However $81 \%$ of students did identify a critical incident and the majority specified either the 'Black Perspectives teaching' or 'personal testimonies' of racism and racial abuse shared by their fellow students as being critical to their overall learning.

\section{Chart 1 Critical Incident Analysis}

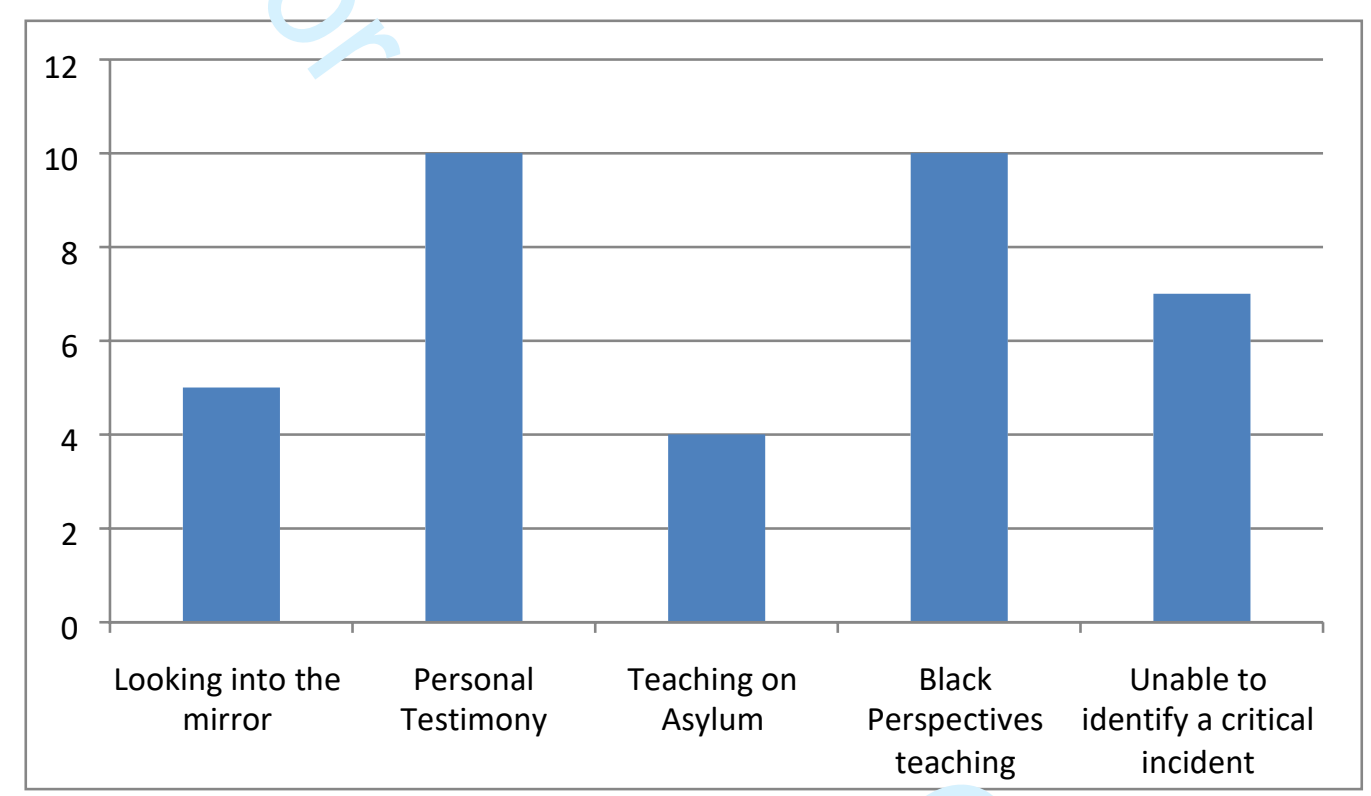

When this data was cross tabulated with age and 'race' the analysis suggested that 'personal testimony' had been particularly critical for the learning of young white students (see table 12) 
Table 12 Critical incident cross tabulation

\begin{tabular}{|c|c|c|c|c|}
\hline Ethnicity & Age & & & Frequency \\
\hline \multirow{10}{*}{ White } & \multirow{4}{*}{ Under 26} & \multirow{4}{*}{ Valid } & Personal Testimony & 6 \\
\hline & & & Teaching on Asylum & 2 \\
\hline & & & Black Perspectives teaching & 2 \\
\hline & & & Total & 10 \\
\hline & \multirow{6}{*}{ Over 26} & \multirow{6}{*}{ Valid } & Looking into the mirror & 4 \\
\hline & & & Personal Testimony & 2 \\
\hline & & & Teaching on Asylum & 2 \\
\hline & & & Black Perspectives teaching & 3 \\
\hline & & & $\begin{array}{l}\text { Unable to identify a critical } \\
\text { incident }\end{array}$ & 3 \\
\hline & & & Total & 14 \\
\hline \multirow{7}{*}{ Black } & \multirow{3}{*}{ Under 26} & \multirow{3}{*}{ Valid } & Black Perspectives teaching & 5 \\
\hline & & & $\begin{array}{l}\text { Unable to identify a critical } \\
\text { incident }\end{array}$ & 2 \\
\hline & & & Total & 7 \\
\hline & \multirow{4}{*}{ Over 26} & \multirow{4}{*}{ Valid } & Looking into the mirror & 1 \\
\hline & & & Personal Testimony & 2 \\
\hline & & & $\begin{array}{l}\text { Unable to identify a critical } \\
\text { incident }\end{array}$ & 2 \\
\hline & & & Total & 5 \\
\hline
\end{tabular}

The data suggested that for 15 students, representing $42 \%$ of the student group, a critical moment in their learning involved the disclosure and sharing of a lived experience of racism (personal testimony and what do you see in the mirror exercise on self and the social world) which was critical in shaping their learning and understanding of anti-racism.

The findings also revealed that a third of Black students, compared with only $12 \%$ of white students, were unable to identify a critical incident. This data seems to suggest that these critical moments in learning were more important for white students in developing and transforming their praxis and critical thinking on anti-racism. 


\section{Overall impressions and reactions to learning}

A sizeable group of predominantly white students stated that they were not sure if the module had addressed their learning needs (see Chart 2). The absence of cultural awareness training was often cited as a reason responsible for this evaluation.

\section{Chart 2 Has the module addressed your learning needs}

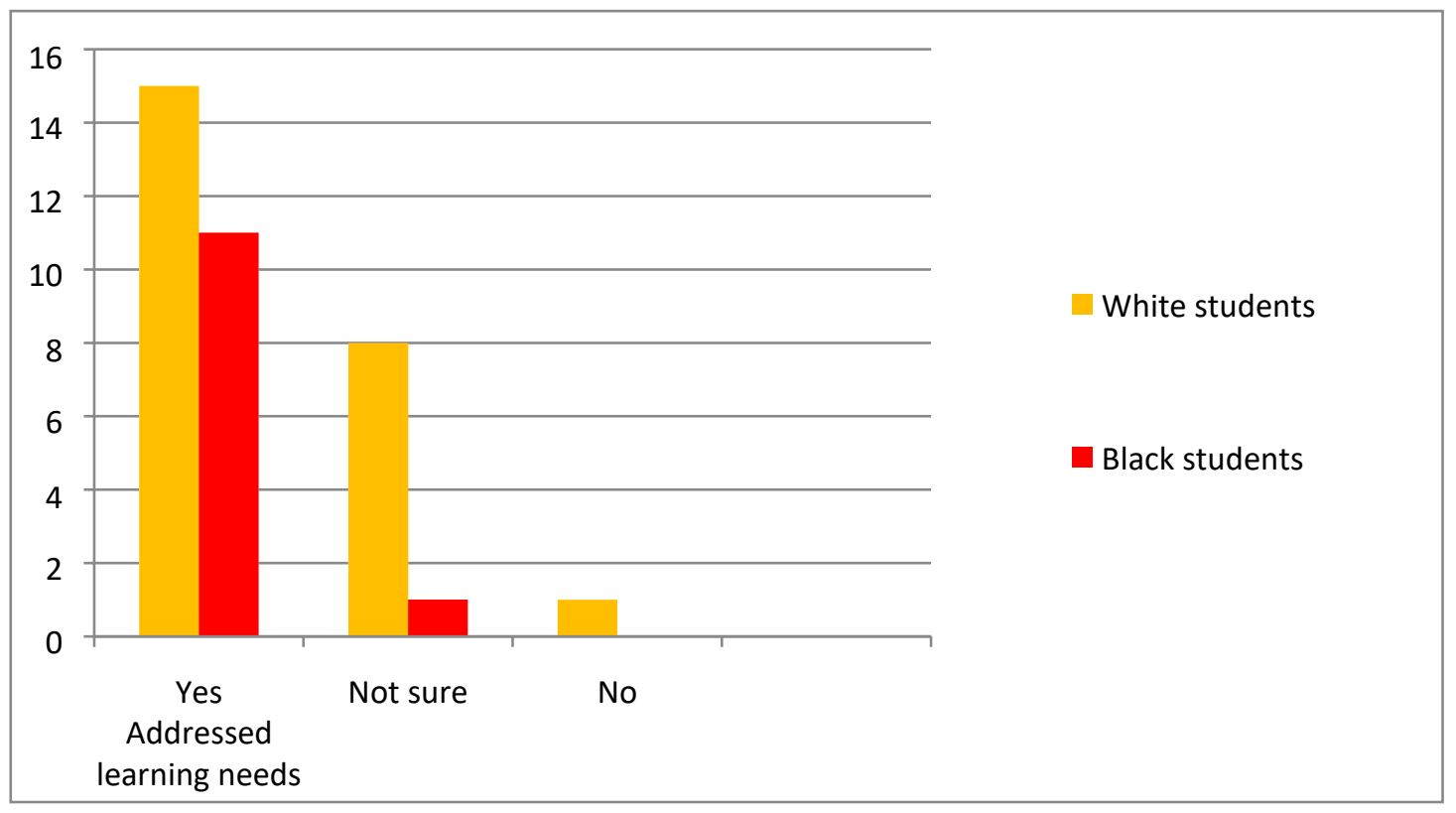

Students were also asked to reflect upon whether there had been too much emphasis on 'race' issues in module teaching (see Table 13). Over a third of the group (36\%) were either unsure or felt that there had been too much emphasis on 'race' issues, to the detriment of exploring other areas of social oppression. This was particularly the case for white students with half of this group suggesting that the teaching may not have been balanced and placed too much emphasis on anti-racism. 
Table 13 Perceptions of module teaching cross-tabulated with 'race'

\begin{tabular}{|l|l|l|l|l|l|l|}
\hline \multirow{2}{*}{} & \multicolumn{2}{|l|}{ Too much emphasis on 'race' issues } & \multirow{2}{*}{ Total } \\
\cline { 2 - 6 } & $\begin{array}{l}\text { Yes - too } \\
\text { much } \\
\text { emphasis on } \\
\text { race issues }\end{array}$ & $\begin{array}{l}\text { No - too little } \\
\text { emphasis on } \\
\text { race issues }\end{array}$ & Not sure & $\begin{array}{l}\text { Well } \\
\text { balanced } \\
\text { approach }\end{array}$ & \\
\hline \multirow{2}{*}{ Ethnicity White students } & $6(25 \%)$ & 0 & $\begin{array}{l}6 \\
(25 \%)\end{array}$ & $12(50 \%)$ & 24 \\
\cline { 2 - 7 } Total & $1(8 \%)$ & $1(8 \%)$ & 0 & $10(83 \%)$ & 12 \\
\hline
\end{tabular}

In group interviews some white students made reference to a 'hierarchy of oppression' and 'double standards' operating on the programme. These perceptions had been shaped by their experiences in class and students suggested that 'race' issues had gained ascendancy and other areas of oppression, particularly sexuality and the experiences of sexual minority groups, were either overlooked or not tackled with the same commitment and vigour by tutors. These students suggested that these experiences had left the cohort 'fractured' and divided across 'race' lines. Some of these students also suggested that they themselves or their peers had adopted an approach to learning, which involved a high degree of self-censoring and consciously keeping participation and engagement to an absolute minimum. Several reasons were given for this minimum engagement and adoption of a strategy to learning which meant "keeping your head below the parapet" but the main ones were linked to 'lack of trust' and 'not feeling safe' in the learning group. However in the group interviews with Black students it was suggested that sexuality and homophobia was consciously being cited and used by some white students to make "generalisations about all black students and to criticise their perspectives on religion and sexuality". These students suggested that some of their white peers had used this as smokescreen not to deal with their own racism. 


\section{Discussion}

\section{Students understanding and experiences of racism}

The questionnaire and group interview data reported in this paper suggested that during the course of teaching students became more conscious of racial oppression. Prior to teaching students lacked an awareness of racial oppression and may have been experiencing 'false consciousnesses' due to the processes of 'interpellation'. The processes on 'interpellation' enable us to understand the way in which ruling class ideology is upheld and reproduced by the ideological and repressive apparatus of the state, which works against the development of class consciousness and an awareness of structural oppression (Althusser,1971). However during the course of teaching, previous understandings and experiences of racism, and how these were made sense of, underwent a process of change and transformation. At $\mathrm{T} 2$ students were more conscious and aware of 'race' issues and previous experiences were revisited and made sense of in light of these new understandings.

It is important to recognise that for some students their personal, professional and political identities were in a state of flux and that anti-racism teaching was exposing them to new learning which particularly on 'Black Perspectives' (Goldstein, 2008), was experienced by some as 'transformational' (Mezirow, 1981); and critical for developing 'critical consciousness' through the process of 'conscientization' (Freire, 1970). This strand of new learning particularly for Black students, may also have been linked to what Robinson (1995) describes as 'nigrescence' (a Latin word used to describe the process of becoming Black and developing a positive Black identity). For some of these students teaching on 'Black Perspectives' may have been a catalyst to becoming more conscious about the nature of colour racism and how it influenced their collective and individual life experiences.

The research evidence also suggests that during the course of teaching students started to identify a set of different skills and issues which they considered to be important for multicultural and anti-racist praxis (see table 4 and 6). The data suggested that students 
had moved beyond what (Williams \& Graham, 2013, p11) call a "rudimentary focus of cultural competency" concerned with "all too often very essentialised" and "first level issues" to a more sophisticated and nuanced understanding by the end of teaching.

At T1 students tended to identify "first level issues" (see table 3 and 5) which could be evidenced in relation to an over-emphasis on cross-cultural communication, access to services and developing an awareness of cultural and faith-based differences (Gillighan \& Furness, 2006). However at T2 a more sophisticated and critically reflexive multi-level understanding of skills and issues was more evident, which was more concerned with racism, asylum and immigration, poverty and social exclusion, authenticity and respect, transcultural practice and advocacy issues.

At T2 students were also identifying more issues and skills and this increase was statistically significant when tested using the Wilcoxon signed matched pairs test. Similarly students' conceptualisations of racial equality and its relevance for social work practice demonstrated change and positive development through the course of teaching. Although students' understanding of racial equality at T1 and T2 remained firmly centred on an 'equality of opportunity' discourse, at T2, students tended to place less emphasis on 'ontological equality' in terms of equal respect. Some students at T2 were also able to make indirect references to 'equality of condition' and 'equality of outcome' (Turner, 1986, p.34) and this demonstrated a more sophisticated and critical understanding of social justice

\section{Evidencing educational outcomes and learners' reactions to learning}

The matched pair data reported in this paper for this study suggests that it is possible to measure "the distance travelled by individual students in their learning" (Braye and Preston-Shoot, 2006, p.83) and to evidence particular types of educational outcomes which address level one and level two of Carpenter's (2005) (after Kirkpatrick, 1967), model of educational outcomes for social work. Level one outcomes are associated with "learners' reaction" and relate to the students' views of their learning experience and satisfaction with the teaching; whilst Level $2 \mathrm{a}$ and Level $2 \mathrm{~b}$ educational outcomes are associated with a "modification in attitudes and perceptions" and the "acquisition of knowledge and skills" (Carpenter, 2005, p.6). 
The level $2 \mathrm{a}$ and $2 \mathrm{~b}$ educational outcomes related to attitude change and knowledge and skill acquisition and can be evidenced in the distance travelled by students, which, when tested using the Wilcoxon matched pairs tests in relation to Confidence, Awareness and Knowledge, reports that it is statistically significant. The interval data for these different matched pairs tests suggest that at the end of teaching students have statistically higher levels of confidence, better awareness and feel more knowledgeable about 'race' issues. In terms of data for overall learning, with the exception of only 2 students, the remainder $(\mathrm{N}=34)$ agreed that the module had developed their understanding of 'race' issues. These positive educational outcomes demonstrate the important of anti-racism in social work training (Bhatti-Sinclair, 2011) and suggest that this particular strand of emancipatory education can lead to a more conscious and committed form of anti-racist practice (Cowden \& Singh,2013).

The different strands of data also enable us to "discover what it is about programmes that works for whom, in what circumstances and in what respects, and why" (Pawson and Tilley, 2004, p.19). The questionnaire data suggests that that this educational intervention was experienced and worked differently for Black and white students. For example teaching was more important in increasing the 'race' awareness levels of white students compared with Black students; whilst the interval data for awareness showed little variance for Black students, the opposite was true for white students, where the change in awareness levels was noticeable and demonstrative of positive learning. This suggests that students experienced some aspects of learning differently and on some occasions this learning addressed particular group learning needs. This was similarly true for Black students when it came to 'Black Perspectives' teaching which all of them cited as a key component of their learning. For white students this teaching did not have the same impact and was experienced differently. Therefore the different types of learning offered seems to have a struck a particular type of chord with specific groups of learners and has left a complex set of tracks which are suggestive of different types of outcomes for different types of students.

These differences were also very apparent in student reactions to the teaching which had taken place on anti-racism and their overall satisfaction with the learning experience. One in three of white students felt that they were not sure whether the 
module had addressed their learning needs. This represented a critical mass of white students who were not completely satisfied with the learning offered. The lack of effectiveness of this teaching to reach out and connect with these students is an area of concern and suggests the need to reappraise and revisit some areas of content and delivery. In group interviews it was suggested that some students had 'simply switched off' and kept participation and engagement to an absolute minimum because of fear of saying the wrong thing and getting it wrong. This 'silencing' was also true for some Black students, who suggested in their group interview that when they spoke about racism they were misheard, not listened to and were generally seen as making "too much noise" (Ahmed, 2012, p.144) about racism. They had therefore decided to refrain from taking these risks associated with speaking about racism and had chosen to become silent.

A significant number of white students in their questionnaire responses also felt that the teaching and learning approach was not well balanced and unduly favoured 'race' issues to the detriment of other areas of social oppression, $50 \%$ of this group suggested that there had either been too much focus on 'race' issues or that they were not sure that the teaching approach had been balanced. On the contrary the majority of Black students demonstrated high levels of satisfaction with the teaching and learning opportunities made available and the type and range of content covered in teaching.

In both of the group interviews involving white students very strong assertions were made that the programme operated double standards and unduly privileged 'race' issues. In group interviews it was suggested that Black students were given special access to tutors and additional academic support via their Black student group. It was also suggested that only 'race' issues were tackled with vigour and commitment, whilst other areas of social oppression, particularly sexuality were addressed superficially and homophobic remarks from Black students were not challenged appropriately and proportionally

This data was useful for understanding why a significant number of white students felt that 'race' issues were in the ascendancy on the programme and why some evaluated their learning less favourably. The absence of cultural awareness training which was 
identified as a key area of learning in questionnaire data by one third of white students may have also influenced some of these overall evaluations. In group interviews students were very vocal about the absence of cultural awareness training and how this impeded their ability to work across cultures. In these interviews students recognised how their lived experiences of multiculturalism were limited and how many of them lacked basic cultural knowledge around religion which they considered to be essential for practice. The apparent absence of cultural awareness training, which is used extensively in other areas of professional education, particularly nurse training (Papadopoulos, 2006), may have influenced some of these responses which were suggestive of learning needs not being addressed and overall dissatisfaction with the learning experience.

However in terms of overall learning a number of important educational outcomes can be evidenced from the empirical evidence reported and triangulated in this paper. These outcomes are suggestive of a general direction of travel which has resulted in positive change and an increased awareness of 'race' issues which can also be evidenced in student confidence and knowledge levels. A more sophisticated understanding of 'race' issues emerges at the end of teaching and for some students this aspect of professional education has been experienced as emancipatory and as a catalyst for political as well as intellectual growth. 


\section{Implications for Practice}

The evidence presented in this paper provides an empirical understanding of how antiracist social work is experienced and the different types of educational outcomes which can be accrued from this teaching intervention in professional training. The research has clear implications for practice in that it enables educators to understand the different footprints this teaching leaves behind and how these differences in reactions to learning; levels of classroom engagement and praxis are often associated with a students age, cultural positioning and their prior practice experience of working with Black and minority ethnic service users. The data presented in this paper enables an understanding of how this learning is experienced differently by Black and white students and why their different learning needs should be differentiated and reflected in different areas of course content to develop preparedness for practice and new strategies, for example in working in white social work organisations and addressing different manifestations of unconscious bias.

The empirical evidence presented in this paper also enables us to understand the practice implications of 'white noise' and how this creates resistance and disengagement from learning. The evidence presented in this paper suggests that some aspects of this dissonance can be overcome by tutors infusing into teaching reflective spaces for intercultural dialogue and encouraging learners to share individual and group experiences of racism and how it creates turbulence in professional practice.

The overall evidence presented in this paper demonstrates how the outcomes of antiracist social work education can be measured and evidenced in educational practice to defend the utility and emancipatory nature of this area of teaching in an often contested and overcrowded social work curriculum. 


\section{References}

Ahmed, S. (2012), On Being Included: Racism and Diversity in Institutional Life, (Durham and London, Duke University Press).

Althusser, L. (1971), Ideology and Ideological State Apparatuses, in: Althusser, L (Ed.), Lenin and Philosophy and Other Essays, (London, New Left Books), http://www.marx2mao.com/Other/LPOE7ONB.html, [Accessed 27 th January 2017].

Anthias, F \& Lloyd, C. (2002), Introduction: Fighting Racisms, Defining the Territory, in: Anthias, F. \& Lloyd, C. (Eds.), Rethinking Anti-Racisms, (London, Routledge), pp. 1-21.

Banks, N. (1999), White Counsellors-Black Clients: Theory Research and Practice, (Aldershot, Ashgate).

Barn, R. (2006) Improving Services to Meet the Needs of Minority Ethnic Children and Families, Research in Practice, (London, Department for Education and Skills).

Bernard C, \& Harris P. (2016). (Eds.). S. e @ uarding Black Children: Good Practice in Child Protection. London. Jessica Kingsley Publisher.

Bhatti-Sinclair, K. (2011), Anti -Racist Practice in Social Work, (Basingstoke, Palgrave).

Bhatti-Sinclair, K. \& Bailey, C. (2010), Evaluating teaching and learning about 'race' and racism, in: Burgess, H. \& Carpenter, J. (Eds.), The Outcomes of Social Work Education: Developing Evaluation Methods, Monograph number 2, (Southampton: SWAP), pp53-61.

Bonnett, A. \& Carrington, B. (1996), Constructions of Anti-Racist Education in Britain and Canada, Comparative Education, 32, 3, pp. 271-288.

Braye, S. \& Preston-Shoot, M. (2006), Teaching, learning and assessment of law in social work education, Social Work Education SCIE Guide 13, (London, Social Care Institute for Excellence).

Bulmer, M. (2004), Editors Introduction: Questionnaires - an Overview, in: Bulmer, M. (Ed.), Questionnaires Vol, III, (London, Sage). 
Burgess, H \& Carpenter, J, (2010), The OSWE Project: collaborating to develop the evaluation of outcomes of social work education, in: Burgess, H. \& Carpenter, J, (Eds.), The Outcomes of Social Work Education: Developing Evaluation Methods, Monograph number 2, (Southampton: SWAP), pp. 7-15.

Butler, A., Elliot, T. \& Stopard, N. (2003), Living up to the Standards we Set: A Critical Account of the Development of Anti-Racist Standards, Social Work Education, 22, 3, pp. 271-282.

Butt, J. (2006), Are We There Yet? Identifying the Characteristics of Social Care Organisations that Successfully Promote Diversity, (Bristol, SCIE \& The Policy Press).

Carpenter, J. (2005), Evaluating Outcomes in Social Work Education, (Social Care Institute for Excellence / Scottish Institute for Excellence in Social Work Education).

Carpenter, J. (2011), Evaluating Social Work Education: A review of outcomes, measures, research designs and practicalities, Social Work Education, 30, 2, pp.122-140.

Casey, L. (2015), Report of Inspection of Rotherham Metropolitan Borough Council, Department for Communities and Local Government, (London, HMSO), https://bit.ly/2EhUcfu [Accessed 28 ${ }^{\text {th }}$ February 2019].

Chand, A. (2008), Every Child Matters? A critical review of child welfare reforms in the context of minority ethnic children and families. Child Abuse Review, Volume 17, number 1, pp.622.

Cowden, S. \& Singh, G. (2013), Sat-Nav Education: A Means to an End or an End to Meaning? in: Cowden, S. \& Singh, G. (Eds.), Acts of Knowing: Critical Pedagogy In, Against and Beyond the University, (London, Bloomsbury), pp.41-60.

Dominelli, L. (1988), Anti-Racist Social Work: A Challenge for White Practitioners and Educators, (Basingstoke, Palgrave). 
Dominelli, L. (2002), Changing agenda's: moving beyond fixed identities in anti-oppressive practice, in: Tomlinson, D.R. \& Trew, W. (Eds.), Equalising Opportunities, Minimising Oppression: A Critical Review of Anti-Discriminatory Policies in Health and Social Welfare, (London, Routledge), pp. 56-71.

Downing, J. \& Husband, C. (2005), Representing "race": Racisms, Ethnicities and Media, (London, Sage).

Equality and Human Rights Commission (EHRC), (2018), Is Britain Fairer? The state of Equality and Human Rights in Britain: Equality, Human Rights Review, (London, EHRC).

https://www.equalityhumanrights.com/en/britain-fairer [Accessed $28^{\text {th }}$ October 2018].

Fernando, S. (2014). Racism in the delivery of Mental Health Services.

https://www.runnymedetrust.org/blog/racism-in-the-delivery-of-mentah-healthservices [Accessed Date: 4th February 2019].

Freire, P. (1970), Pedagogy of the Oppressed, (London, Penguin).

Gilligan, P. \& Furness, S. (2006), The Role of Religion and Spirituality in Social Work Practice: Views and Experiences of Social Workers and Students, British Journal of Social Work, 36, 4, pp. 617-637.

Gilligan, P. \& Furness, S. (2010), Religion, belief and social work practice: Making a difference, (Bristol, Policy Press).

Goldstein, B. P. (2008), Black Perspectives, in: Davis, M. (Ed.), The Blackwell Companion to Social Work, (Third Edition), (Oxford, Blackwell), pp. 515-422.

Gray, A. (2003), Research for Cultural Studies, (London, Sage).

Green, R., Pugh, R. \& Roberts, D. (2008), Black and minority ethnic parents with mental health problems and their children, SCIE Research Briefing 29, (London, Social Care Institute for Excellence). 
Heron, G. (2006), Critical Thinking in Social Care and Social Work: Searching Student Assignments for the Evidence, Social Work Education, 25, 3, pp. 209-224.

Heron, G. (2008), Using Students' Written Feedback on 'Race' Issues to Enhance Self-Regulated Learning, British Journal of Social Work, 38, 2, pp. 376-394.

Jeyasingham, D. (2012), White Noise: A Critical Evaluation of Social Work Education's Engagement with Whiteness Studies, British Journal of Social Work, 42,4, pp.669-686.

Johnson, R. B. \& Onwuegbuzie, A. J. (2006), Mixed Methods Research: A Research Paradigm Whose Time Has Come, in: Bryman, A. (Ed.), Mixed Methods, Volume 1, (London, Sage).

Joseph Rowntree Foundation, (2012), How has ethnic diversity grown 1991-2001-2011? Dynamics of Diversity: Evidence from the 2011 Census, (University of Manchester, ESRC Centre on Dynamics of Ethnicity).

Keating, F. (2012), Theorising 'race', ethnicity and mental health, in: Craig, G., Atkin, K., Chattoo, S. \& Flynn, R. (Eds.), Understanding 'Race' and Ethnicity, (Bristol, Policy Press). pp.209226.

Keating, F., Robertson, D., McCulloh, A. \& Francis, E. (2002), Breaking the Circles of Fear, (London, The Sainsbury Centre for Mental Health).

Khan, O, \& Shaheen, F. (2017), Introduction: Analysing and Responding to Racial and Class Inequalities, in Khan, O, \& Shaheen, F. (Eds.), Race and Class in post Brexit Britain, (London, Runnymede Trust).

Kohli, R.K.S. (2007), Social Work with Unaccompanied Asylum Seeking Children, (Basingstoke, Palgrave Macmillan).

Laird, S. E. (2008), Anti-Oppressive Social Work Practice: A Guide for Developing Cultural Competence, (London, Sage). 
Lavalette, M. \& Penketh, L. (2014), Race, racism and social work, in: Lavalette, M. \& Penketh, L. (Eds.), Race, Racism and Social Work: Contemporary issues and debates, (Bristol, Policy Press), pp.1-16.

Lishman, J. (1999), Introduction, in: Shaw, I. \& Lishman, J. (Eds,), Evaluation and Social Work Practice, (London, Sage), pp. 1-14.

McLaughlin, K. (2005), From Ridicule to Institutionalization: Anti-Oppression, the State and Social Work, Critical Social Policy, 25, 3, pp. 283-305.

Mezirow, J. (1981), A Critical Theory of Adult Learning and Education, Adult Education Quarterly, 32,1, pp. 3-24.

Modood, T. (1992), Not Easy Being British: Colour, Culture and Citizenship, (London, Runneymede Trust and Trentham Books).

Modood, T. (2013), Multiculturalism, (Second Edition), (Cambridge, Polity Press).

Orme, J \& Shemmings, D. (2010), Developing research based social work, (Basingstoke, Palgrave Macmillan).

Papadopoulos, I. (2006), The Papadopoulos, Tilki and Taylor Model of Developing Cultural Competence, in: Papadopoulos, I. (Ed.), Transcultural Health and Social Care:

Development of Culturally Competent Practitioners, (London, Churchill Livingstone), pp. 7-24.

Patel, K. \& Strachan, R. (1997), Anti-Racist Practice or Heuristics! Practice, Social Work in Action, 9, 3, pp. 15-26.

Pawson, R. \& Tilley, N. (1997), Realistic Evaluation, (London, Sage).

Pawson, R \& Tilley, N. (2004), Realistic Evaluation, http://www.communitymatters.com.au/RE chapter.pdf, [accessed $17^{\text {th }}$ January 2019]. 
Platt, L. (2011), Understanding Inequalities: Stratification \& Difference, (Cambridge, Polity Press).

Penketh, L. (2000), Tackling Institutional Racism, Anti-Racist Policies and Social Work Education and Training, (Bristol, Policy Press).

Race Disparity Audit. (2017), Race Disparity Audit, Cabinet Office.

https://www.ethnicity-facts-figures.service.gov.uk/static/race-disparity-audit-summaryfindings.pdf [Accessed 9th May 2018].

Robinson, L. (1995), Psychology for Social Workers: Black Perspectives, (London, Routledge).

Sharma, S. (2006), Multicultural Encounters, (Basingstoke, Palgrave Macmillan).

Singh, G. (2002), The Political Challenge of Anti-Racism in Social Care and Health, in: Tomlinson, D. R. and Trew, W. (Eds.), Equalising Opportunities, Minimising Oppression : A Critical Review of Anti-Discriminatory Policies in Health and Social Welfare, (London, Routledge), pp.72-81.

Singh, G. (2006), Postmodernism, Anti-Racism and Social Work, in: Farrar, M and Todd, M. (Eds.), Teaching 'Race' in Social Sciences: New Context, New Approaches, (C-SAP), (The Higher Education Academy Network, University of Birmingham), pp.72-109.

Singh, S. (2011), ${ }^{3}$ reference redacted in order to preserve the confidentiality of the participants in this study ${ }^{2}$.

Singh, S. (2014), What are the experiences and outcomes of anti-racist social work education? http://sro.sussex.ac.uk/id/eprint/48607/1/Singh, Sukhwinder.pdf [Accessed 9th May 2018].

Spencer, M. S. (Ed.). (2018). Microaggressions and social work education [Special issue]. Journal of Ethnic \& Cultural Diversity in Social Work, 27(1).

Tedam, P. \& Ajoa, A. (2017), The W Word, witchcraft labelling and child safeguarding in social work practice, (London, Critical Publishing). 
Tomlinson, D. R. (2002), From Equal Opportunities to Anti-Oppressive Practice, the Historical and Social Context, in: Tomlinson, D. R and Trew, W. (Eds.), Equalising Opportunities, Minimising Oppression A Critical Review of Anti-Discriminatory Policies in Health and Social Welfare, (London, Routledge), pp.5-29.

Williams, C. (1999), Connecting Anti-Racist and Anti-Oppressive Theory and Practice: Retrenchment or Re-appraisal? British Journal of Social Work, 29, 2, pp. 211-230.

Williams, C. (2011), The Jesters Joke, in: Lavalette, M. (Ed.), Radical Social Work Today: Social work at the crossroads, (Bristol, Policy Press), pp.59-77.

Williams, C. (2014), The catalysers: 'black' professionals and the anti-racist movement, in: Lavalette, M. \& Penketh, L. (Eds.), Race, Racism and Social Work: Contemporary issues and debates, (Bristol, Policy Press), pp.53-70.

Williams, C., Hold, M. \& Kimani, S. (2009), Race Equality and 'Cultural Competency' in Qualifying Social Work Education in Wales, (Wales, Ethnicity Research Collaboration Unit).

Williams, C. \& Graham, M. (2013), Travelling hopefully: race/ethnic relations and social work research: a transnational dialogue, in: Williams, C. \& Graham, M. (Eds.), Social Work in Europe: Race and Ethnic Relations, (London, Routledge), pp. 1-15.

Williams, C, \& Parrot, L. (2013), From Specialism to Genericism: Rising and falling to the challenges of responding to racial and ethnic diversity in social work education in Wales, British Journal of Social Work, 43,6, pp.1206-1224.

Williams, C. \& Soydon, H. (2005), When and how does Ethnicity Matter? A Cross- National Study of Social Work Responses to Ethnicity in Child Protection Cases, British Journal of Social Work, 35,6, pp. 901-920. 